\title{
A RARE RIBBON-GOBY OXYMETOPON CYANOCTENOSUM (ACTINOPTERYGII: PERCIFORMES: GOBIOIDEI: MICRODESMIDAE): THE FIRST AND NORTHERNMOST RECORD FROM TAIWAN
}

\author{
Keita KOEDA ${ }^{1 *}$ and Hsuan-Ching $\mathrm{HO}^{1,2}$ \\ ${ }^{1}$ National Museum of Marine Biology \& Aquarium, Checheng, Pingtung, Taiwan \\ ${ }^{2}$ Institute of Marine Biology, National Dong Hwa University, Pingtung, Taiwan
}

Koeda K., Ho H.-C. 2019. A rare ribbon-goby Oxymetopon cyanoctenosum (Actinopterygii: Perciformes: Gobioidei: Microdesmidae): the first and northernmost record from Taiwan. Acta Ichthyol. Piscat. 49 (1): 85-87.

\begin{abstract}
Species of the genus Oxymetopon (Gobioidei: Microdesmidae) have never been recorded from Taiwanese waters. The main objective of this paper is to document the presence of this genus in the waters of Taiwan. A single specimen (99.2 mm standard length) of genus Oxymetopon was collected from south-western Taiwan in 2017. The morphology and fresh coloration of the collected specimen are herein described. The majority of the morphological characters of the specimen closely matched the diagnostic features of Oxymetopon cyanoctenosum Klausewitz et Condé, 1981 given by the previous study: ray in first dorsal-fin not elongated, tip of depressed rays just reach origin of second dorsal-fin origin; longest first dorsal-fin length shorter than body depth; dorsal crest high, approximately half of the diameter of pupil; tip of depressed pelvic fin reach to analfin origin; pelvic-fin length longer than pectoral-fin length. Therefore, the specimen from south-western Taiwan is identified as Oxymetopon cyanoctenosum. This species has previously been known only from Philippines, Indonesia, and Papua New Guinea. The presently reported specimen represents the first record for Taiwan, as well as the northernmost record of this species up to now.
\end{abstract}

Keywords: Oxymetopon compressus, taxonomy, distribution, South China Sea

\section{INTRODUCTION}

The genus Oxymetopon Bleeker, 1868 belongs to the wormfish (family Microdesmidae), and is characterized by strongly laterally compressed head and body, the presence of dorsal crest on the head, and large gill slit (Chan 1996, Klausewitz and Condé 1981). The species of this group are sheltering in burrows at silt or mud bottom areas. This genus currently comprises 5 valid species occurring in the western Pacific (Prokofiev 2016), however, some species appear to be rare, and none of them have been recorded in Taiwan.

A single specimen of Oxymetopon cyanoctenosum Klausewitz et Condé, 1981 was recently collected off Kaohsiung south-western Taiwan. This species was previously known only from region of East Indies (Allen and Erdmann 2012, Fricke et al. 2018). In Taiwan, only two microdesmids, Gunnellichthys curiosus Dawson, 1968 and Gunnellichthys viridescens Dawson, 1968, were recorded previously (Ho et al. 2013, Ho and Lin 2016). Therefore, the new specimen is herein described as the first record of the genus Oxymetopon and the species O. cyanoctenosum in Taiwan, and the third reliable and northernmost records of this species.

\section{MATERIALS AND METHODS}

Counts and measurements follow Prokofiev (2016). Measurements were made to the nearest $0.1 \mathrm{~mm}$ with needle-point callipers under a dissecting microscope. Standard and head lengths are abbreviated as SL and $\mathrm{HL}$, respectively. The morphological description is based on the specimen collected from Taiwan. The specimen of O. cyanoctenosum examined in this study is deposited at the Pisces collection of the National Museum of Marine Biology \& Aquarium (NMMB-P).

Specimen examined. NMMB-P29845, $99.2 \mathrm{~mm} \mathrm{SL}$, off Kaohsiung, obtained at Ke-tzu-liao Fish Landing Port, 17 August 2018, bottom trawling, coll. by H.-C. Ho.

\section{RESULTS}

Family Microdesmidae

Subfamily Ptereleotrinae

Oxymetopon Bleeker, 1868

窄顱塘鱧屬

Oxymetopon cyanoctenosum Klausewitz et Condé, 1981 藍梳窄覤頁塘鱧

Fig. 1

“ Correspondence: Dr Keita Koeda, 944屏東縣車城鄉後灣村後灣路2號，Taiwan， phone: (+866) 966543754, e-mail: (KK) hatampo@gmail.com, (HH) hohc@nmmba.gov.tw. 
Oxymetopon cyanoctenosum Klausewitz et Condé, 1981; Klausewitz and Condé 1981: 71, fig. 1, 10-17, 19e (type locality: probably from off Cebu, Philippines); Allen and Adrim 2003: 61; Allen and Erdmann 2012 (in part): 995; Fricke et al. 2014: 178; Prokofiev 2016: 136.

Description of NMMB-P29845. Counts: first dorsal-fin rays $\mathrm{VI}$; second dorsal-fin rays $\mathrm{I}+31$; anal-fin rays $\mathrm{I}+$ 31 ; pectoral-fin rays 20 ; pelvic-fin rays $\mathrm{I}+4$; caudal-fin rays ix $+8+7+$ viii; total gill rakers in first arch 26 ; pseudobranchial filaments 16; vertebral formula $10+$ 16; dorsal pterygiophore formula 3-2211. Measurements (as percent of SL): head length $15.9 \%$; pectoral-fin length $18.0 \%$; pelvic-fin length $38.2 \%$; caudal-fin length $40.6 \%$; maximum body depth $18.0 \%$; minimum body depth $9.0 \%$; length of caudal part of body $49.2 \%$; horizontal diameter 4.4\%; upper jaw length 7.5\%. Body elongate, its maximum depth 5.5 times in SL and analfin origin to caudal-fin base 2.0 times in SL; body and head strongly compressed laterally. Dorsal profile of head almost straight from snout to above preopercle with sharp notch above eye. Dorsal crest present above head, its height almost half of pupil diameter. Ventral profile of head gently rounded from snout to pelvic-fin origin. Dorsal and ventral profiles almost straight posterior to dorsal- and pelvic-fin origins. Snout very short; eye located close to dorsal profile. Nostrils located at just anterodorsal of eye. Mouth strongly oblique, forming angle of $70^{\circ}$ to horizontal; lower jaw projecting than upper jaw. Gill opening large, lowermost point at same level of ventral margin of preopercle; gill membrane of both sides connecting at isthmus. Jaws with two to three rows of minute conical teeth anteriorly, and single row posteriorly; two pairs of fang-like teeth of anterior parts of jaws. Origin of first dorsal fin slightly posterior to vertical above pelvic-fin origin; spines of first dorsal-fin short, filaments absent, last two spines just reaching origin of second dorsal fin when depressed; base of second dorsal fin longer than that of first; soft rays of second dorsal fin longer posteriorly; soft rays of posterior half of second dorsal fin longer than longest first dorsal-fin spine. Origin of anal fin below base of fourth soft ray of second dorsal fin; length of first ray of anal fin almost half of other rays. Pectoral fin short, posterior tip not reaching vertical drawn through posterior end of dorsal-fin base. Origin of pelvic fin slightly posterior to base of pectoral fin; pelvic fin rays very long as filaments, most of rays reaching base of seventh anal-fin ray. Caudal fin diamond-shape, middle rays longer than upper and lower rays.

Coloration - When fresh, body and head uniformly greyish-blue; abdomen metallic light-blue with 11 faint yellow vertical bands; faint dusky radial stripes at anterodorsal to anteroventral of eye; small faint dusky blotches at opercle; dorsal crest on head dusky with yellow outer margin snout faintly yellowish. Dorsal, pectoral, and pelvic fins yellowish translucent; anal fin faintly dusky posteriorly; caudal fin yellowish with dusky vertical stripes.

When preserved, body and head uniformly pale brown with 22 brownish vertical stripes throughout body, paler posteriorly; seven brown longitudinal bars on abdomen; pectoral-fin base followed by brown bar; two small brown blotches above pectoral fin. Brown radial stripes at anterodorsal to anteroventral of eye; small brown blotches on opercle and preopercle; basal part of dorsal crest at head brown; lips brown. Second dorsal and anal fins pale, posteriorly brownish; caudal fin light brown with brown vertical stripes.

Distribution. Oxymetopon cyanoctenosum is currently known from the Philippines, Indonesia, and Papua New Guinea (Allen and Adrim 2003, Allen and Erdmann 2012, Fricke et al. 2018), and now from south-western Taiwan (presently reported study).
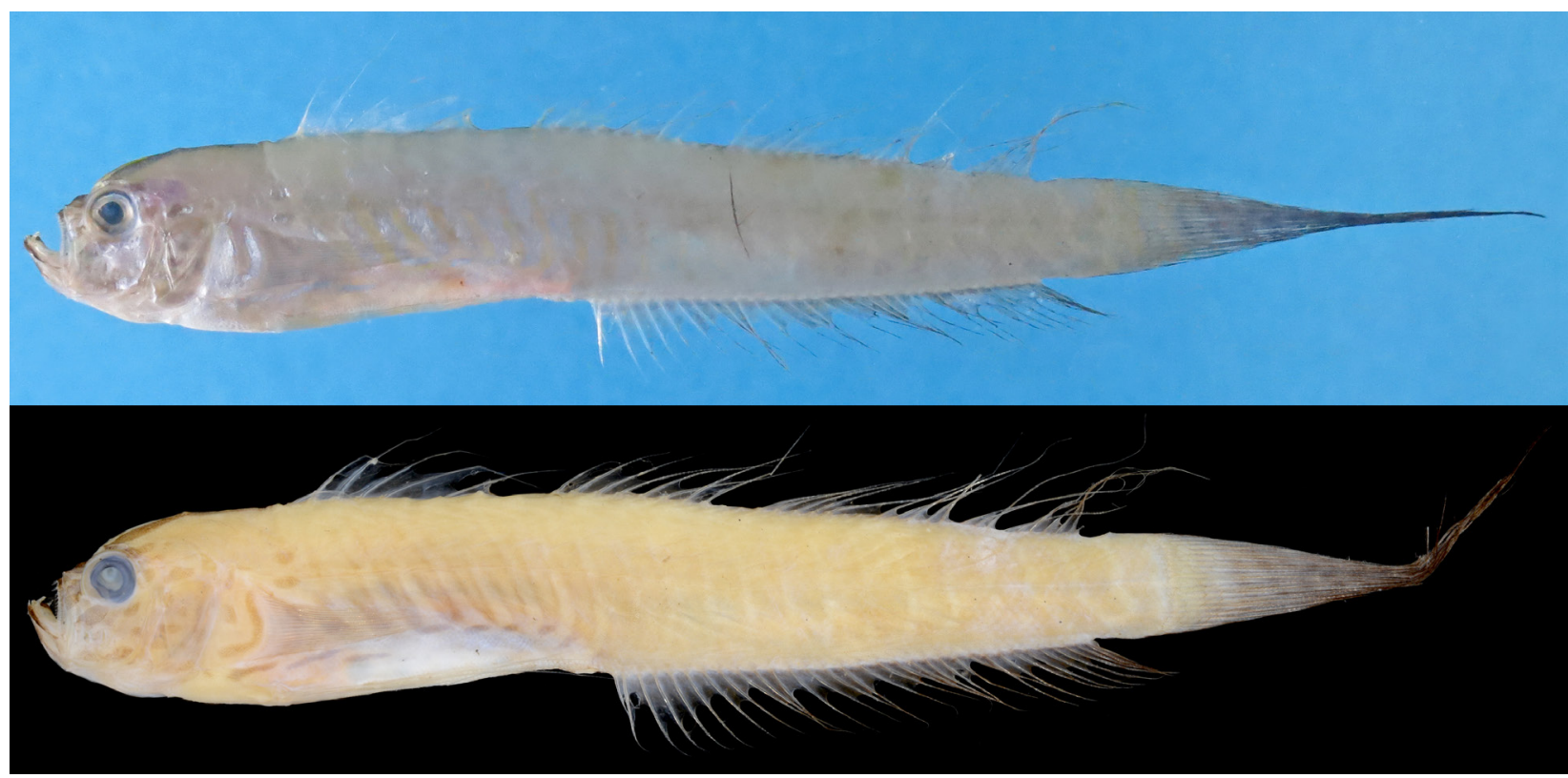

Fig. 1. Fresh (upper) and preserved (lower) specimen of Oxymetopon cyanoctenosum from south-western Taiwan; NMMB-P29845, 99.2 mm SL 


\section{DISCUSSION}

The majority of morphological characters of the presently reported specimen match those from the keys of Prokofiev (2016): ray in first dorsal-fin not elongated, tip of depressed rays just reach origin of second dorsalfin origin; longest first dorsal-fin length shorter than body depth; dorsal crest high, approximately half of the diameter of pupil; tip of depressed pelvic fin reach to analfin origin; pelvic-fin length longer than pectoral-fin length.

Among its congeners, Oxymetopon cyanoctenosum is most similar to Oxymetopon compressus Chan, 1966 in having dorsal-fin spines shorter than maximum body depth and relatively high dorsal crest which approximately half of the diameter of pupil (Prokofiev 2016). Oxymetopon cyanoctenosum can clearly distinguish from $O$. compressus in having tip of the depressed pelvic fin reach to the anal-fin origin in the former (vs. do not reach anus in the latter); pelvic-fin length longer than pectoral fin length (vs. shorter).

Oxymetopon cyanoctenosum was originally described by Klausewitz and Condé (1981) from a single specimen collected probably from Cebu Island in Philippines. Allen and Adrim (2003) reported a second record on the basis of specimen collected from Maumere Bay, Flores, Indonesia. No reliable records known for the species after their report. Allen and Erdmann (2012) shown underwater photo of this species in their field guide, but the photo was likely $O$. compressus with relatively short pelvic fin. In summary, the present report represents the third reliable record of $O$. cyanoctenosum, as well as, the northernmost record of the species.

\section{ACKNOWLEDGEMENTS}

We are especially grateful to Y. Ikeda (Imperial Household Agency) for providing reference and some comments. We also thank R.-R. Chen, J.-T. Lin, and J.-F. Huang (National Museum of Marine Biology \& Aquarium) for curatorial assistance. The presently reported study was supported in part by the Japan Society for the Promotion of Science Overseas Research Fellowships (29-304) to the first author.

\section{REFERENCES}

Allen G.R., Adrim A. 2003. Coral reef fishes of Indonesia. Zoological Studies 42 (1): 1-72.

Allen G.R., Erdmann M.V. 2012. Reef fishes of the East Indies. Volumes 1-3. Tropical Reef Research, Perth WA, Australia.

Chan W.L. 1966. Oxymetopon compressus, a new eleotrid fish from Hong Kong. Japanese Journal of Ichthyology 14 (1-3): 1-3. DOI: 10.11369/jji1950.14.1

Fricke R., Allen G.R., Andréfouët S., Chen W.-J., Hamel M.A., Laboute P., Mana R., Hui T.H., Uyeno D. 2014. Checklist of the marine and estuarine fishes of Madang District, Papua New Guinea, western Pacific Ocean, with 820 new records. Zootaxa 3832: 1-247. DOI: 10.11646/zootaxa.3832.1.1

Fricke R., Eschmeyer W.N., van der Laan R. (eds.) 2018. Catalog of fishes: Genera, species, references. California Academy of Sciences, San Francisco, USA. [Accessed on 25 September 2018.] http://researcharchive.calacademy.org/research/ ichthyology/catalog/fishcatmain.asp

Ho H.-C., Lin C.-T. 2016. New records of three coral reef fishes from the Kenting National Park, Taiwan. Platax 13: 79-83.

Ho H.-C., Lin C.-J., Yang C.-R. 2013. New records of five fish species from the Green Island, Orchid Island and Kenting, Taiwan. Platax 10: 73-80.

Klausewitz W., Condé B. 1981. Oxymetopon cyanoctenosum, n. sp., un nouvel Eléotride des Philippines, avec une étude compare du genre (Pisces, Perciformes, Gobioidei, Eleotridae). Revue française d'Aquariologie, Herpétologie 8 (3): 67-76.

Prokofiev A.M. 2016. Genus Oxymetopon (Microdesmidae: Ptereleotrinae) in the coastal areas of Province Khanh Hoa (Vietnam, South China Sea). Journal of Ichthyology 56 (2): 175-180. DOI: 10.1134/ S0032945216020144

Received: 26 June 2018

Accepted: 2 October 2018

Published electronically: 15 March 2019 